\title{
Examining the Effectiveness of Catch Crops as a Nature-Based Solution to Mitigate Surface Soil and Water Losses as an Environmental Regional Concern
}

\author{
Artemi Cerdà $\cdot$ Iván Franch-Pardo ${ }^{2} \cdot$ Agata Novara $^{3} \cdot$ Srikanta Sannigrahi $^{4} \cdot$ Jesús Rodrigo-Comino $^{5}$ (i)
}

Received: 28 July 2021 / Revised: 3 December 2021 / Accepted: 3 December 2021 / Published online: 27 December 2021

(c) The Author(s) 2021

\begin{abstract}
The main goal of this research was to conduct a biophysical, economic, social, and perception-based approach to foresee the solutions that could be used to mitigate the soil loss problem cost-effectively in "La Ribera del Xúquer" district (Valencia Region, Spain). To achieve these goals, a farmer perception survey was carried out, and an assessment of the biophysical impact of catch crops on soil organic matter, bulk density, steady-state infiltration rate (double-ring infiltrometer) and runoff generation, and soil erosion (rainfall simulation experiments) was carried out in 2016. For the biophysical approach, two paired plots, i.e., catch crops vs. glyphosate herbicide treatment (in advance, control plot), were selected under clementine citrus production. The results show that soil organic matter increased from 1.14 to $1.63 \%$, and bulk density decreased from 1.47 to $1.27 \mathrm{~g} \mathrm{~cm}^{-3}$ after 10 years of treatments using catch crops. They also facilitated higher infiltration rates from 16.7 to $171 \mathrm{~mm} \mathrm{~h}^{-1}$ and a delay in runoff generation from 149 to $654 \mathrm{~s}$ for control and catch crop plots. Both runoff rates (from 50.6 to $3.1 \%$ ) and soil erosion (from 3.9 to $0.04 \mathrm{Mg} \mathrm{ha}^{-1} \mathrm{~h}^{-1}$ ) were reduced once the catch crops were deployed in the field. After surveying (2018-2019), farmers stated the use of catch crops as a speck of dirt and a cause of possible loss of reputation when used. Moreover, farmers $(N=73)$ would accept the catch crops as an effective nature-based alternative only if a subsidy of $131.17 € \mathrm{ha}^{-1}$ would be paid. The survey results also demonstrated that the farmers' community would see catch crop more as a benefit for the planet's health and society. Few constraints, such as ageing of the farmers' population, lack of education and negative perception for other management factors, are the critical detrimental factors for adopting catch crops as a nature-based solution to reduce soil and water losses. There is a need for an effective agrarian extension service to change the fate of the current agriculture and achieve sustainability by adopting new management strategies in contemporary agricultural practices.
\end{abstract}

Keywords Citrus orchards $\cdot$ Control measures $\cdot$ Sustainability $\cdot$ Regional geography $\cdot$ Land management

Jesús Rodrigo-Comino

jesusrc@ugr.es

Artemi Cerdà

artemio.cerda@uv.es

Iván Franch-Pardo

ifranch@enesmorelia.unam.mx

Agata Novara

Agata.novara@unipa.it

Srikanta Sannigrahi

srikanta.sannigrahi@ucd.ie

1 Soil Erosion and Degradation Research Group, Department of Geography, Valencia University, Blasco Ibàñez, 28,

46010 Valencia, Spain
2 Universidad Nacional Autónoma de México, Escuela Nacional de Estudios Superiores, 58190 Morelia, Michoacan, Mexico

3 Dipartimento Scienze Agrarie, Alimentari e Forestali, University of Palermo., Viale Delle Scienze, Building 4, 90128 Palermo, Italy

4 School of Architecture, Planning and Environmental Policy, University College Dublin, Dublin, Ireland

5 Departamento de Análisis Geográfico Regional y Geografía Física, Facultad de Filosofía y Letras, University of Granada, Campus Universitario de Cartuja, 18071 Granada, Spain 


\section{Introduction}

Soil conservation is the key for maintaining food production, soil health, and the functionality of terrestrial ecosystems to enable the achievement of the Sustainable Development Goals (SDG) of the United Nations, specifically the SDG15.3 that focus explicitly on Land Degradation Neutrality (LDN) and improving the quality of land ecosystems services (Keesstra et al. 2018a, 2021). In addition, the European Commission has set two ambitious targets, i.e., $75 \%$ of all European soils will be healthy by 2030 , and $25 \%$ of all agriculture will be managed organically by 2030 (Veerman et al. 2020). The success of these targets is closely associated with soil health and related ecosystem functions. However, in contemporary agriculture practices, the unscientific overuse of chemical fertilizers, herbicides and pesticides, and intense tillage has often led to severe soil degradation, especially in the Mediterranean region (Guillaume et al. 2016; Kamau et al. 2017; Kuzyakov and Zamanian 2019). Far too often, soils are not adequately managed, despite their crucial role in the functioning of terrestrial biogeochemical cycles, plant and animal nutrition, and the success of human societies (Bragança et al. 2019; Ferrara et al. 2014; Trivedi et al. 2016). For example, unsustainable practices such as intensive uses of chemical fertilizers in agricultural systems can seriously increase soil erosion processes (Borrelli et al. 2020; Guerra et al. 2020; Katra 2020; Nearing et al. 2017). Therefore, a new soil management framework is necessary to control the accelerated soil erosion and maintain agricultural sustainability for keeping the supply of varied soil ecosystem services uninterrupted (García-Ruiz et al. 2020; Liu et al. 2020; Minea et al. 2019).

Rural areas in the Mediterranean regions are severely affected by soil degradation and high-level soil erosion. In the traditional agricultural regions, non-sustainable cultivation practices have been the cause of onsite soil degradation on arable land and the source of the sediments that reach rivers, reservoirs, and wetlands (Raclot et al. 2009; Taguas and Gómez 2015). Several scholars have outlined many critical determining factors of soil erosion in the Mediterranean, including steep slopes, poor soils, heavy rains, and eradicating all vegetation other than the crop itself (Martínez-Valderrama et al. 2016; Novara et al. 2021). Until the 1960s, intense tillage practices affected soil structure and facilitated organic matter mineralization through chemical weathering. Since then, the use of high horsepower tractors has caused irreparable soil disturbances. In recent years, the use of the herbicide has increased in non-irrigated crops, which has led to less vegetation cover and soil surface crusting and compaction, which eventually increased the rate of soil erosion (Marques et al. 2020). Casalí et al. (1999) measured soil losses of $13.3 \mathrm{Mg} \mathrm{ha}^{-1}$ year $^{-1}$ on gullied agricultural land in Navarre. Martínez-Casasnovas et al. (2002) reported $207 \mathrm{Mg} \mathrm{ha}^{-1}$ soil loss in Lleida after a $205 \mathrm{~mm}$ rainfall event that lasted $135 \mathrm{~min}$. Studies at the Pyrenean Institute of Ecology demonstrated that the highest soil loss (15 $\mathrm{Mg} \mathrm{ha}^{-1}$ year $^{-1}$ ) was sourced from fallow fields that were ploughed but not sown after 2- or 3 -years of crop production, a practice that is traditionally done in the Mediterranean region and was promoted by the Common Agriculture Policy (García-Ruiz et al. 1995). The pioneering work conducted by Lasanta and Sobrón (1988) on traditional ploughing practices in vineyards in La Rioja showed that soil erosion rates have reduced up to $<1 \mathrm{Mg} \mathrm{ha}^{-1}$ year $^{-1}$ due to the presence of vegetation cover on the upper soil surface. This demonstrates that vegetation cover is the key factor that controls soil loss. The available data confirm that agricultural lands contribute to soil exhaustion, and controlling soil erosion is the first step to achieving sustainability.

Soil erosion rates on agricultural land in Mediterranean environments depend on the type of crop that is grown. Soil losses are negligible where vegetation cover is present (Lieskovský and Kenderessy 2014; de Torres et al. 2018). The latest research findings on soil erosion for agricultural land in Spain show that non-sustainable soil losses are widespread (Ben-Salem et al. 2018; Taguas et al. 2015), and more research is necessary to control soil erosion by water and tillage. The non-sustainable soil erosion rates in Spain found by the pioneers mentioned here were confirmed over the last decades by many other researchers (Merchán et al. 2019; Rodríguez Sousa et al. 2019; Sastre et al. 2016; Zuazo et al. 2020).

The State-of-the-Art of soil erosion in citrus plantations shows that a few studies targeted citrus erosion and that the current situation shows unsustainable soil erosion rates (Niu et al. 2021). In Spain, these studies have demonstrated high erosion rates in the orchards of Eastern Spain. However, there are no measurements in other regions such as Andalusia, Extremadura, and Murcia. Spain is one of the largest citrus producers and has the largest citrus crop area in Europe. The lack of sustainable management occurs even though the production of citrus fruits is of great economic importance in Spain. One of the stalwarts from Valencia produces over $70 \%$ of the total Spanish citrus yield. In addition, the citrus land has increased by $20 \%$ from 1982 to 2002 , and new non-registered citrus establishments likely double this figure. Other Mediterranean regions of Spain, such as Extremadura, Murcia, and Andalucía, show similar increases in the Valencia Region.

Spanish citrus production has grown from sustainable management in the traditional orchards of alluvial plains and fluvial terraces of Xúquer, Túria, and Segura River basins in 
Murcia and Valencia, to unsustainable plantations on slopes without terraces. The distance between plants is a function of the dimensions of the machinery to be used and the size of the adult crown, which depends mainly on the climate, soil and the pattern, so, in most cases, it will be necessary to compare with situations similar ecological ones to take them as a reference. The average planting density can be estimated at around 400 trees ha $^{-1}$. They require fertilizers (macro and micronutrients), which accounts for a large part of the costs, since it frequently suffers from deficiencies, highlighting the magnesium deficiency, which is closely related to the excess of potassium and calcium and that is solved with foliar applications. Another common deficiency is zinc. The iron deficit is linked to limestone soils, with the application of chelates that represent a scarce solution and a considerable cost. Iron chelates are necessary for soils under high $\mathrm{pH}(<7.5)$. Usually, it does not start fertilizing until the beginning of the second sprouting from the plantation. It will be fertilized at each irrigation from March to September. The water needs of this crop range between 6000 and $7000 \mathrm{~m}^{3} \mathrm{ha}^{-1}$. Because citrus does not have a specific fruiting organ, pruning is well adapted to mechanization and toping and hedging are usually carried out. The soil is tilled several times a year (3-4), from March to September with small power rototillers, or with medium-type tractors; keeping the soil with vegetative cover the rest of the year. Another practice is to tillage the soil in spring to incorporate fertilizers, followed by treatment with residual herbicide and contact or translocation treatments when and where necessary. Semi-no-till, with vegetative cover in winter and bare soil in summer, applying herbicides to the whole field or in stands is also widespread.

These new mechanized production systems have replaced the traditional production systems based on flood irrigation in the valley bottoms and dry farming on terraced hillsides. These new farming systems are widespread in provinces such as Málaga, Seville, Huelva, Badajoz, Murcia, Alicante, Valencia, and Castellón. Similar changes were found elsewhere (Tercan and Dereli 2020; Xu et al. 2018). Traditional flood irrigation and modern drip irrigation contribute to constructing the largest orchard of citrus managed by farmers in small farms in the last century. One of those farms is managed by Vicent Borràs in L'Alcudia, in the heart of "La Ribera del Xúquer." "La Florentina" is a lighthouse where organic farming is being developed since the ' $90 \mathrm{~s}$ and where management is tested to achieve a solution to the highly degraded soils after decades of abuse of pesticides and mineral fertilizers. The consequences of this intensive citrus plantation management, combined with high chemical usage, have increased erosion rates and soil degradation, as was demonstrated in the past (Duan et al. 2020; Hondebrink et al. 2017; Novara et al. 2019). Some authors demonstrated that soil properties such as an increase in bulk density, decrease in organic matter and deterioration of soil structure were registered in citrus plantations (Jianjun et al. 2017; Wang et al. 2010).

The recent mechanization of agriculture has increased the rates and extend of the area affected. Soil erosion has been deeply studied in Spain, but now it is time for the next step: to find strategies to reduce the soil losses (Calatrava and Franco 2020; Novara et al. 2021; van Leeuwen et al. 2019). So far, scientific research has mainly concentrated on characterizing and understanding the mechanisms and processes of soil erosion. Now, based on a good understanding of the soil erosion process, it is necessary to design soil conservation strategies to achieve sustainable environmental management. The research on citrus orchards proposed in this project will focus on management that will reduce soil losses and induce recovery of soil health. The research developed here can be applied to other citrus production regions where soil erosion rates are also found unsustainable, for example, in China (Duan et al. 2020; Jianjun et al. 2017; Zhang et al. 2020), but also to the non-researched areas of citrus production in Florida, California, India, Argentina or Australia. This is also found in other regions of the world such as a recent review shown (Niu et al. 2021).

Nowadays, studies related to farmer perceptions are scarce in the scientific literature combined with soil erosion studies and applying control measures (Sastre et al. 2016). These studies are more common in rural areas of Africa where water scarcity, financial resources and extreme land degradation processes are taking place (Assefa and Hans-Rudolf 2016; Bayu 2020; Biratu and Asmamaw 2016). Fortunately, in the Valencia region, in recent years, the first results are being obtained in olive orchards (Rodrigo-Comino et al. 2020) or vineyards (Cerdà and Rodrigo-Comino 2021). Catch crops could be a solution as they are nature-based solutions (Keesstra et al. 2018b; Nesshöver et al. 2017) but little is known about farmers' deep understanding of nature's functioning and the process involved. By working with the forces of nature, catch crops are well-designed to measure that needs much less maintenance, are highly cost-effective and are effective over long periods as nature will contribute to reinforce the catch crops effects (i.e., weeds) and will contribute to a sustainable economy (i.e., use seeds from other farmers). Therefore, the main objective of this investigation is to apply a multifaceted and multidisciplinary approach to understand land degradation processes in citrus plantation with a plot biophysical approach in a farm that is a lighthouse for the new agriculture (La Florentina farm) but also considering a regional geography approach (La Ribera del Xúquer district) in Valencia citrus production area, Eastern Spain. 
Table 1 Demographic and spatial characterization of the La Ribera district as a representative citrus production region of the study area

\begin{tabular}{|c|c|c|c|c|}
\hline Municipality & $\begin{array}{l}\text { Population } \\
N\end{array}$ & $\begin{array}{l}\text { Surface } \\
\mathrm{Km}^{2}\end{array}$ & $\begin{array}{l}\text { Density } \\
\mathrm{n} \mathrm{Km}\end{array}$ & $\begin{array}{l}\text { Interviews } \\
N\end{array}$ \\
\hline Alberic & 10,330 & 27.0 & 383 & 3 \\
\hline Alcàntera de Xúquer & 1397 & 3.4 & 411 & 1 \\
\hline Alfarb & 1423 & 20.6 & 69 & 0 \\
\hline Algemesí & 27,272 & 41.5 & 657 & 5 \\
\hline Alginet & 12,605 & 24.1 & 523 & 1 \\
\hline Almusafes & 8967 & 10.8 & 833 & 1 \\
\hline Alzira & 44,440 & 110.4 & 390 & 4 \\
\hline Antella & 1526 & 17.6 & 87 & 3 \\
\hline Beneixida & 670 & 3.2 & 209 & 1 \\
\hline Benicull & 1012 & 3.6 & 284 & 2 \\
\hline Benifaió & 12,204 & 20.1 & 607 & 1 \\
\hline Benimodo & 2141 & 12.5 & 171 & 1 \\
\hline Benimuslem & 605 & 4.2 & 144 & 1 \\
\hline Carcaixent & 21,695 & 59.2 & 366 & 5 \\
\hline Càrcer & 2095 & 7.6 & 276 & 2 \\
\hline Carlet & 15,189 & 45.6 & 333 & 1 \\
\hline Castelló de la Ribera & 7493 & 20.3 & 369 & 1 \\
\hline Catadau & 2619 & 35.5 & 74 & 0 \\
\hline Corbera & 3100 & 20.3 & 153 & 1 \\
\hline Cotes & 373 & 6.0 & 62 & 1 \\
\hline Cullera & 22,145 & 53.8 & 412 & 2 \\
\hline Favareta & 2518 & 9.4 & 268 & 2 \\
\hline Fortaleny & 1026 & 4.6 & 223 & 1 \\
\hline Gavarda & 1171 & 7.8 & 150 & 1 \\
\hline Guadassuar & 5943 & 35.3 & 168 & 0 \\
\hline l'Alcúdia & 11,105 & 23.7 & 469 & 5 \\
\hline l'Ènova & 1011 & 7.7 & 131 & 1 \\
\hline la Pobla Llarga & 4420 & 10.1 & 438 & 3 \\
\hline Llaurí & 1170 & 13.6 & 86 & 2 \\
\hline Llombai & 2600 & 55.6 & 47 & 0 \\
\hline Manuel & 2570 & 6.0 & 428 & 1 \\
\hline Massalavés & 1652 & 7.5 & 220 & 1 \\
\hline Montroi & 2500 & 31.4 & 62 & 0 \\
\hline Montserrat & 5452 & 45.6 & 120 & 0 \\
\hline Poliñá de Júcar & 2472 & 9.2 & 269 & 1 \\
\hline Rafelguaraf & 2453 & 16.3 & 150 & 3 \\
\hline Real & 2150 & 18.3 & 117 & 0 \\
\hline Riola & 1759 & 5.6 & 314 & 1 \\
\hline Sallent de Xàtiva & 454 & 14.0 & 32 & 1 \\
\hline Sant Joanet & 413 & 1.9 & 217 & 1 \\
\hline Senyera & 1141 & 2.0 & 571 & 2 \\
\hline Sollana & 4861 & 39.2 & 124 & 3 \\
\hline Sueca & 27,477 & 92.5 & 297 & 3 \\
\hline Sumacàrcer & 1296 & 20.1 & 64 & 3 \\
\hline Torís & 6053 & 80.5 & 75 & 0 \\
\hline Tous & 1152 & 127.5 & 9 & 0 \\
\hline Total & 297,480 & 1247 & 238.57 & 73 \\
\hline
\end{tabular}

\section{Materials and Methods}

\subsection{Study Area}

"La Ribera del Xúquer" is the oldest commercial citrus production region in Europe and is known as one of the most extensive surfaces and production of citrus. In 2019, they achieved 84,000 ha of citrus, which is the largest production district in the Valencia region (160,000 ha), and Spain (297,600 ha of citrus land). La Ribera del Xúquer region is composed of 47 municipalities. In total, they cover a $1247 \mathrm{~km}^{2}$ geographical area and almost 300,000 inhabitants, with a population density of 238.6 inhabitants per $\mathrm{km}^{2}$. The population density is highly varied, ranging from 9 in Tous to 657 inhabitants per $\mathrm{km}^{2}$ in Algemesí (Table 1). The total amount of the population is also unevenly distributed, with 373 inhabitants in Cotes and 44,440 in Alzira, which is the capital of the district. The surface of the municipality ranged from $1.9 \mathrm{~km}^{2}$ in San Joanet to $127.5 \mathrm{~km}^{2}$ in Tous. The main area covered by citrus plantations is in the centre of the alluvial plain of the Xúquer river. However, the citrus plantations' last century growth was highest in the pediment and alluvial fans; this could be due to the availability of water pumped from the aquifer or the irrigation ditches. In the last 30 years, the expansion was due to the drip irrigation that allowed new plantations in the foot slopes where the soil is shallow.

The climate at the La Ribera is typically the Mediterranean, characterized by a recurrent summer drought. This is why the irrigation system is well developed since the middle age from local spring, the main Xúquer River, and since the end of the nineteenth century with wells and pumps. The mean annual rainfall is $550 \mathrm{~mm}$ year $^{-1}$, and the yearly average temperature is about $15.8{ }^{\circ} \mathrm{C}$ at the study site (Novara et al. 2019). The "La Ribera del Xúquer" is a coastal region that receives the warm and wet winds from the Mediterranean that resulted in high-intensity rainfall events and then the risk of soil erosion. Since then, the two plots selected to develop the research were researched since 2002, and a survey of the management was carried out since then. In both plots, limestone colluvium is the main parent material and soil texture uses to be sandy clay loam with an Ap horizon over a $\mathrm{Bt}$ (clay) subsoil horizon. In general, in this region, soils can be classified as Anthrosols if they are transformed or conserve past conditions as calcaric Cambisols, Fluvisols or Regosols (IUSS Working Group WRB 2015). They have on the top a mixed Ap horizon during the orchard establishment with low organic matter content $($ even $<1 \%)$, weak aggregation, and relative high calcium carbonate content $(\sim 5 \%)$. 


\subsection{Plot Characteristics and Sampling Strategy}

Two paired-neighbouring plots $\left(1000 \mathrm{~m}^{2}\right)$ were selected with a citrus plantation with two different soil management types (Fig. 1). The Catch Crop (CC) site is, under the organic farming rules (EU) following the supervision of the Valencia Organic Farming Committee (Comité d'Agricultura Ecologica Comunitat Valenciana). The CC study site applies no-machine to conduct the annual soil management, and the field is chipped three times per year (April, June, and August) during the growing season, meanwhile, in winter the weeds are not removed due to the reduced growth. "Chipping" means in our study area mowing the vegetation and leaving it on the surface as mulch. The CC study was covered by catch crops (oat -Avena sativa L.- and vetch -Vicia sativa L.-) sowed using a disc seedling machine during October. In the winter period, manure was applied on the surface in a dose of $5 \mathrm{Mg} \mathrm{ha}^{-1}$. During the vegetated season, pruned and chipped residues as used as mulch in a dose of $80 \mathrm{~kg} \mathrm{ha}^{-1}$ year $^{-1}$ and applied on the surface each April, June and August. Mowing was applied during the winter period. Organic mulch was left on the surface. Hedges with aromatic plants and shrubs are present on the farm, too, to increase the biodiversity. Figure 2 shows a view of the study sites.

The Control plot (C) was located at $39^{\circ} 10^{\prime} 47.71^{\prime \prime} \mathrm{N}-0^{\circ}$ $33^{\prime} 23.40^{\prime \prime} \mathrm{W}$ and the Catch Crops crop at $39^{\circ} 10^{\prime} 49.70^{\prime \prime}$ $\mathrm{N}-0^{\circ} 33^{\prime} 27.53^{\prime \prime} \mathrm{W}$. We applied a paired-plot approach to find the impact of the catch crop in two separated blocks of plots with trees planted at $4 \times 6 \mathrm{~m}$. Soil sampling took place at each of the research plots (Catch Crops and Control) before the rainfall simulation experiments, and they were collected at two different depths (0-2 and 4-6 cm) as those layers are the key to understanding the soil detachment and runoff generation.

The Control plot applies chemical fertilization with NPK $8 / 4 / 12$ at a rate of $150 \mathrm{~kg} \mathrm{ha}^{-1}$ year $^{-1}$. The soil is treated with herbicides (glyphosate) at least three times per year. The pruned branches are collected by a tractor and burnt. A Lamborghini tractor (674-70SPRINT) is used in the plot. The tires of the front and rear wheels are 320-24 and 480-30, respectively. The wheelbase is $2056 \mathrm{~mm}$.

\subsection{Farmer's Perception Survey}

To evaluate farmers' perception of soil management in the study region of "La Ribera del Xúquer" district, a survey was carried out from 2018-2019 (August 2018 till July 2019). To get insights into the perception of the use of $\mathrm{CC}$ and $\mathrm{C}$, a set of questions (see Table 2) were addressed to 73 farmers. The questions were formulated to get a reply (yes or no) from the farmer, and it was recorded as 0 (no) and 1 (yes). The questions were formulated to understand the farmers' knowledge
Control (C)

Catch Crops (CC)

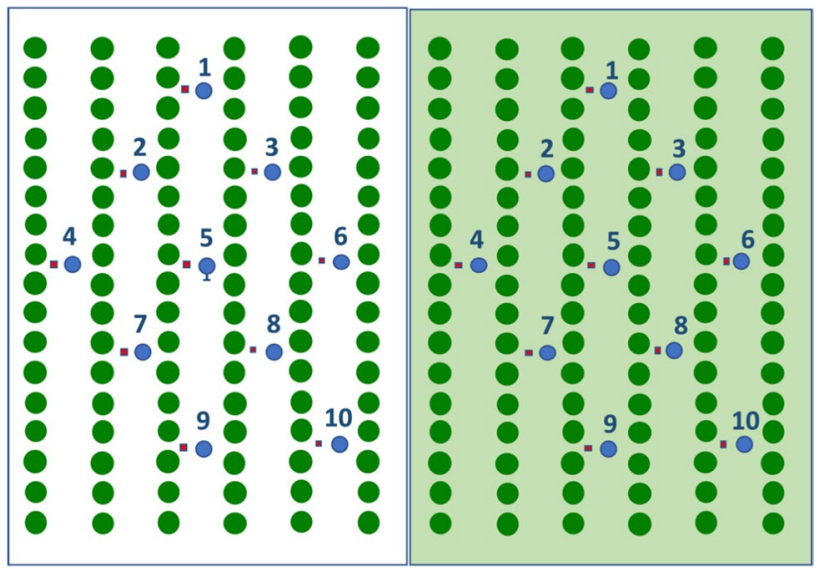

- Sampling plot $\bigcirc$ Rainfall Simulation plot $\bigcirc$ Citrus tree

Fig. 1 Sampling layout in the control and catch crops plots

about catch crops and other strategies to reduce soil losses, their perception of sustainable management, and how it can be promoted (subsidies). The gender and age of the farmer were also recorded and the municipality where they were coming from (Table 2). The interview was carried out in the fields while the farmers and the interviewers visited the farmer's fields. While the farmer was informed about the variety of citrus, production, management, cost of fertilizers, pruning and irrigation, the interviewers introduced the topics shown in Table 2, where information about the farmer's opinion about catch crops is found.

\subsection{Plant and Soil Analysis}

The sampling strategy along the two tested plots is shown in Fig. 1. Plant, litter, rock fragment, and bare soil covers were measured before rainfall simulation experiments and were determined by counting 100 points regularly distributed at each $0.25 \mathrm{~m}^{2}$ plot (Fig. 2 shows both control and catch crop plots). Samples were collected in the summer (August) to assess the biomass of the catch crop cover. Each sample was collected at a $0.25 \mathrm{~m}^{2}$, and all the surface plants were sown and transported to the laboratory. Then, they were dried at $60{ }^{\circ} \mathrm{C}$ to determine the dry matter. The catch crop was sown each year in October and chipped in April, June and August. The biomass was surveyed after sowing $1 \mathrm{~m}^{2}$ in each plot as a representative area. The sample was weighed in the field and then dried $\left(60{ }^{\circ} \mathrm{C}\right)$ in the laboratory and weighed again to determine the dry biomass. The drying period was 3 days or until the dry weight reached a steady-state value. Those calculations allow us to determine the moisture and dry matter found 
Fig. 2 View of the study sites and experimental setup. A View of the Catch Crop (CC). B View of a Control plot (C). C View of a Catch Crop plot. D View of a Control plot. E Rainfall simulation and double-ring infiltrometer during the experiments. And E rainfall simulator view
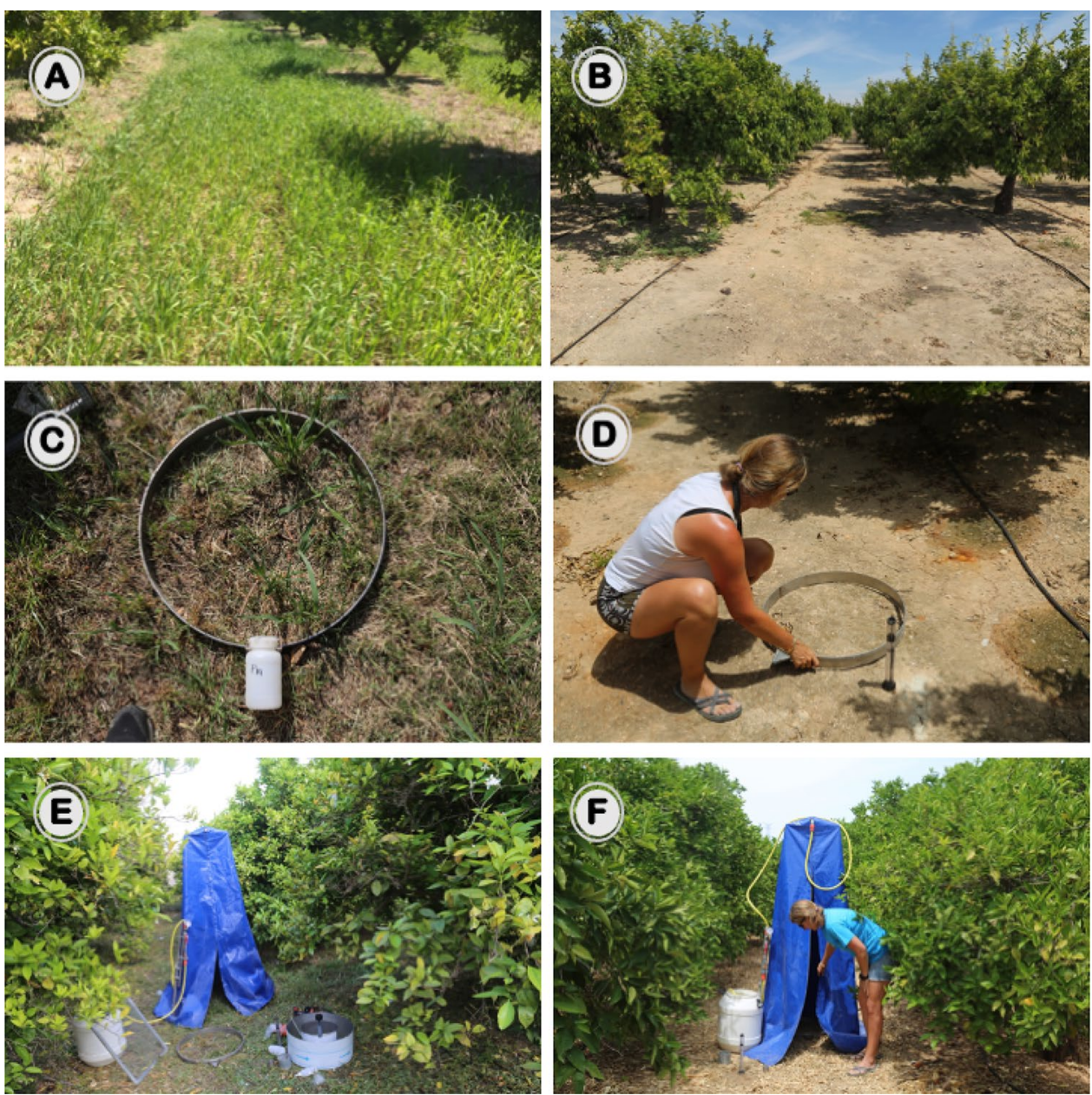

in the Control and Catch Crop plots. We show here the total biomass.

Grain size, organic matter and bulk density were determined at each soil sample up to $25 \mathrm{~cm}$ soil depth with a shovel with at least three repetitions following a near vicinity of each rainfall simulation experiment. The pipette method was used to determine soil texture (Deshpande and Telang 1950). Bulk density was measured using the ring method (undisturbed samples). Soil organic matter was measured using the Walkley-Black method (Walkley and Black 1934). Soil moisture was determined by the desiccation method.

\subsection{Ring Infiltration Measurements and Rainfall Simulation Experiments}

In July 2016, a field campaign was carried out with simulated rainfall experiments and a ring infiltrometer to test the impact of the contrasted management on soil properties and soil and water losses. A double-ring infiltrometer (Fig. 2d) was used to determine the steady-state infiltration rate. Depth of ponded water in the double-ring infiltrometer was taken at 1, 2, 5, 10, 15, 20, 25, 30, 35, $40,45,50,55$ and $60 \mathrm{~min}$, and after each reading, the cylinders were filled again to keep the head as constant as possible. The infiltration envelope was fitted to the Horton equation to calculate the steady-state infiltration rate. The measurements in the control plots were carried out 2 weeks after the tractor passes for tillage.

Twenty (ten-paired plots) rainfall simulation experiments were also carried out at $55 \mathrm{~mm} \mathrm{~h}^{-1}$ rainfall intensity for one hour on circular paired plots $\left(0.25 \mathrm{~m}^{2}\right)$ in summer 2016. At each plot, runoff flow was collected at 1-min intervals, and water volume was measured. The runoff coefficient was calculated as the percentage of rainfall water leaving the circular plot as overland flow. Runoff samples were desiccated $\left(105^{\circ} \mathrm{C}, 24 \mathrm{~h}\right)$, and sediment yield was calculated on a weight basis to estimate soil loss per area and time $\left(\mathrm{Mg} \mathrm{ha}^{-1} \mathrm{~h}^{-1}\right)$. During the rainfall simulation experiments, time to ponding (time required for $40 \%$ of the surface to be ponded; $\mathrm{Tp}, \mathrm{s}$ ), time to runoff initiation ( $\mathrm{Tr}, \mathrm{s}$ ) and time needed by runoff to reach the outlet (Tro, s) were recorded. Tr-Tp and Tro-Tr were calculated, and they indicate how the ponding is transformed into runoff 
and how much time the runoff on the soil surface needs to reach the plot outlet. These parameters are good indicators of the hydrological connectivity within the plot (Cerdà et al. 2021a, b).

\subsection{Statistical Analysis}

Infiltration and runoff characteristics were represented in the form of spider web and box plot graphics with averages and 5th and 95th percentiles. Soil characteristics, biomass production and rainfall simulation results were expressed in tables with averages, standard deviation $( \pm)$, maximum and minimum values. Then, they were compared to assess the significant differences in both paired plots. First, we conducted a t-test using Sigma Plot 14.0 (Systat Software Inc.). Since some results did not follow a normal distribution (normality test and Shapiro-Wilk), we used a Tukey test or Holm-Sidak test at the $P<0.001$ level to avoid the normality assumption in the analysis. Finally, linear interrelations were

Table 2 Farmer's opinion about the use of catch crops and the impact of subsidies, chemicals, and the future of citrus production $(N=73)$

\begin{tabular}{|c|c|c|}
\hline Questions $(N=73)$ & Yes $\left(N^{\circ}\right)$ & Yes $(\%)$ \\
\hline Female & 8 & 10.96 \\
\hline How old are you? & 49.43 & Years \\
\hline How much you must be subsidized to use catch crops & 131.2 & $€ \mathrm{ha}^{-1}$ \\
\hline Do you know what Vetch is? & 51 & 69.86 \\
\hline Do you know what Oats is? & 58 & 79.45 \\
\hline Do you know what Alfalfa is? & 59 & 80.82 \\
\hline Do you know what a catch crop is? & 7 & 9.59 \\
\hline Do you know what soil erosion is? & 66 & 90.41 \\
\hline Is soil erosion a problem for soil fertility? & 18 & 24.66 \\
\hline Is soil erosion a problem for vehicles and transport? & 65 & 89.04 \\
\hline Do you like to have catch crops in your orchard? & 18 & 24.66 \\
\hline Do you use catch crops in your orchard & 3 & 4.11 \\
\hline Do you think catch crops reduce soil losses? & 20 & 27.40 \\
\hline Do catch crops because enhancing infiltration? & 22 & 30.14 \\
\hline Do catch crops compete with the water for the orchards and damage the production? & 24 & 32.88 \\
\hline Do you think catch crops improve soil quality? & 4 & 5.48 \\
\hline Is catch-crop dirt management? & 69 & 94.52 \\
\hline Do you avoid catch crops because is more expensive & 25 & 34.25 \\
\hline Do you avoid catch crops because of enhancing pests?? & 50 & 68.49 \\
\hline Would you use catch crops if they will be subsidized? & 30 & 41.10 \\
\hline Is the use of catch crops improving your reputation as a farmer? & 1 & 1.37 \\
\hline Do the catch crops increase your income? & 0 & 0.00 \\
\hline Is organic farming a solution for the farmer? & 13 & 17.81 \\
\hline Is organic farming a solution for the farmer because of economic issues? & 27 & 36.99 \\
\hline Is organic farming a solution for the farmer because of health issues? & 37 & 50.68 \\
\hline Is chemical farming a problem for the farmer because of health issues? & 44 & 60.27 \\
\hline Do you have a successor for your farm? & 30 & 41.10 \\
\hline The use of chemicals will affect future generations? & 63 & 86.30 \\
\hline Have you been in contact with chemicals that are now recognized as no healthy? & 69 & 94.52 \\
\hline Did the EU policies (subsidies) improved the environmental conditions of your region?? & 39 & 53.42 \\
\hline Did you see an improvement in the economy after the EU applied the CAP in your region? & 29 & 39.73 \\
\hline Did you see an improvement in the economy in the last 10 years for the farmers? & 10 & 13.70 \\
\hline Does it depend on the subsidies for the success of organic farming? & 49 & 67.12 \\
\hline Are you sick of subsidies and the bureaucracy involved in them? & 68 & 93.15 \\
\hline The payment will make the community will see you as a clever farmer because of the extra income? & 61 & 83.56 \\
\hline Is the payment to compensate for the loss of credibility or reputation because of the use of catch crops? & 56 & 76.71 \\
\hline Must subsidies cover the extra cost of water and fertilizers to maintain the catch crop cover? & 60 & 82.19 \\
\hline Must the EU (CAP) pay the cost of seeds and sowing in catch crops? & 58 & 79.45 \\
\hline
\end{tabular}


estimated to observe possible trends depending on the plot, treatment, soil property and erosion.

\section{Results}

\subsection{Farmer's Perception in La Ribera del Xúquer Region}

The 73 interviews with farmers in "La Ribera del Xúquer" district inform about their perception about sustainable management of the soil and new strategies to avoid the use of herbicides, and they are shown in Table 2. Farmers are on average 49-year-old (33 out of 73 are older than 60) and mainly men (12 women out of 73 farmers interviewed). $67 \%, 80 \%$, and $81 \%$ of the farmers know about vetch, oat, and alfalfa. However, only $10 \%$ of the farmers are aware of catch crops. The farmers of la Ribera del Xúquer know the concept of erosion (90\%), although 50\% of them live in a flat area. However, most farmers expressed their disagreement about soil erosion as a problem despite knowing soil erosion causes a reduction of soil fertility and crop production (25\%). However, they believe vehicles and transports are the primary sources of the problem in the region as the same expedite the gully and rill development that eventually leads to soil erosion (90\%).

Few farmers would like to have catch crops in the orchard $(25 \%)$. Three out of 73 farmers have shown catch crops or weed in the orchard, and $27 \%$ recognized that catch crops could reduce soil losses. Similar values, i.e., $31 \%$ of the farmers believed that catch crops are enhancing soil erosion. However, a few farmers also responded that catch crop could be a damaging plant which reduces the plant available water content (33\%) and enhances infiltration (27\%). The negative perception of farmers' opinions is that they damage the crop. Additionally, a few farmers acknowledged that there is more fauna in the areas with covers such as weeds and catch crops, but they consider this as unfavourable as wild animals visit those farms daily and damage the equipment such as drip irrigation or fences. This is why farmers of this region showed their interest in herbicide as the best management option as the same could keep the soil clean and tidy with no vegetation cover except the crop. A significant number of farmers (95\%) believed that catching crops are a dirty management option that does not improve the soil quality $(5.5 \%)$. The reason is that it is more expensive management (34\% for the catch crops) as it enhances pest (68\% for the catch crops), and farmers that they would use only if subsidized (41\%). Only one farmer out of 73 agrees that catch crops improve the reputation of the farmers. No one trust that the catch crops increase their income. And as a consequence, few farmers accept organic farming as a solution (37\%). Farmers agree that organic farming can improve the economic issue (51\%) and their health (60\%), and $86 \%$ of the farmers accept that chemical (conventional) farming is unhealthy for them and future generations.

From the social point of view, $41 \%$ of the farmers do not have a successor for their farms. They informed us that along with their lives as farmers, and they were in contact with unhealthy chemical products $(95 \%)$, those now are not allowed to be applied in the field due to proven adverse effects on human health. Most of the farmers (64\%) agree that the EU policies improved the region's environmental conditions. Still, the economic improvement is less accepted (53\%), and only $40 \%$ found that the economy was upgraded in the last decade. They assume that organic farming can only be successful with subsidies $(67 \%)$. This is related to the farmers' demand to be subsidized the seeds and the sowing of the catch crops $(67 \%)$. Seventy-seven percent of the farmers say that this payment is to compensate for the loss of reputation because catch crops (84\%) and the EU subsidy payment will show the farmer as a clever fellow (84\%).

Farmers indicate that the subsidies and bureaucracy are making them sick of the system (92\%), but that they will accept a payment of $131.2 € \mathrm{ha}^{-1}$ for catch crops as a subsidy to cover all the expenses and the lack of reputation within the farmer's community as a clean and tidy orchard should have no other plants than the citrus.

\subsection{Biomass Production and Soil Properties}

The vegetation cover at the plots and their fresh biomass and dry biomass production are shown in Table 3. In the Control plots, the ones treated with glyphosate (control), the vegetation cover was negligible as plant cover was $1.8 \%$ of the plot, and the catch crops reached $83.5 \%$ cover. The fresh biomass collected was $1.84 \mathrm{~g} \mathrm{~m}^{-2}$ at the control plot. Meanwhile, the ones covered with catch crop achieved $352.28 \mathrm{~g} \mathrm{~m}^{-2}$ on average for the 10 individual plots. This was 0.22 and $14.08 \mathrm{~g} \mathrm{~m}^{-2}$ dry biomass for the control and catch crop plots, respectively, not showing significant differences. The amount of moisture in the catch crop and control vegetation was similar: 87.45 and $95.63 \%$, respectively.

In Table 4, the plant, litter and stone cover registered at each plot is shown. The average values inform about a contrasted situation between the CC (73.5\% cover of plants) and the $\mathrm{C}(1.1 \%)$. On the contrary, the litter and the stone cover are similar (below 3\%). Soil organic matter shows higher values at the CC (1.63\%) and lower at C (1.14\%). Bulk density also shows a contrasting response with 1.47 and $1.26 \mathrm{~g} \mathrm{~cm}^{-3}$ for the $\mathrm{CC}$ and $\mathrm{C}$ plots, respectively. Statistical analysis shows that almost all the properties show a significant difference among them at $P<0.001$. Only SWC obtained similar results $(P=0.615)$. 
Table 3 Plant cover, biomass (fresh and dry), moisture and dry matter values

\begin{tabular}{|c|c|c|c|c|c|c|c|c|c|c|c|c|}
\hline \multirow{3}{*}{$\begin{array}{l}\text { Unit } \\
N=10\end{array}$} & \multirow{2}{*}{\multicolumn{2}{|c|}{$\frac{\text { Plant cover }}{\%}$}} & \multirow{2}{*}{\multicolumn{2}{|c|}{$\frac{\text { Fresh biomass }}{\mathrm{g}}$}} & \multirow{2}{*}{\multicolumn{2}{|c|}{$\frac{\text { Fresh biomass }}{\mathrm{g} \mathrm{m}^{-2}}$}} & \multirow{2}{*}{\multicolumn{2}{|c|}{$\frac{\text { Dry biomass }}{\mathrm{g} \mathrm{m}^{-2}}$}} & \multirow{2}{*}{\multicolumn{2}{|c|}{$\frac{\text { Moisture }}{\%}$}} & \multirow{2}{*}{\multicolumn{2}{|c|}{$\frac{\text { Dry matter }}{\%}$}} \\
\hline & & & & & & & & & & & & \\
\hline & $\overline{\mathrm{C}}$ & $\mathrm{CC}$ & $\overline{\mathrm{C}}$ & $\mathrm{CC}$ & $\overline{\mathrm{C}}$ & $\mathrm{CC}$ & $\overline{\mathrm{C}}$ & $\mathrm{CC}$ & $\overline{\mathrm{C}}$ & $\mathrm{CC}$ & $\overline{\mathrm{C}}$ & $\mathrm{CC}$ \\
\hline Av & 1.80 & 83.50 & 0.44 & 88.07 & 1.74 & 352.28 & 0.22 & 14.08 & 87.45 & 95.63 & 12.55 & 4.37 \\
\hline $\mathrm{Sd}$ & 1.48 & 8.67 & 0.13 & 32.80 & 0.52 & 131.20 & 0.07 & 3.92 & 2.89 & 1.43 & 2.89 & 1.43 \\
\hline Max & 4.00 & 97.00 & 0.65 & 139.00 & 2.60 & 556.00 & 0.36 & 23.85 & 90.00 & 97.82 & 19.15 & 6.43 \\
\hline Min & 0.00 & 72.00 & 0.24 & 54.20 & 0.96 & 216.80 & 0.12 & 10.65 & 80.85 & 93.57 & 10.00 & 2.18 \\
\hline $\mathrm{VC}(\%)$ & 81.98 & 10.38 & 29.61 & 37.24 & 29.61 & 37.24 & 31.79 & 27.82 & 3.30 & 1.49 & 23.01 & 32.68 \\
\hline Diff & $P<0.001$ & & $P<0.001$ & & $P<0.001$ & & $P<0.001$ & & $P<0.001$ & & $P<0.001$ & \\
\hline
\end{tabular}

$C$ Control plot, $C C$ Catch crop plot, $A v$ average, $S d$ standard deviation, Max maximum, Min minimum, $V C$ variation coefficient $((\mathrm{Sd} / \mathrm{Av}) \times 100)$, Diff. statistical significant differences

Significance at $P<0.05$

Table 4 Plant, litter and stone cover, soil organic matter (SOM), bulk density (BD) and soil water content at the 10 catch crops and 10 control rainfall simulation plots

\begin{tabular}{|c|c|c|c|c|c|c|c|c|c|c|c|c|}
\hline $\begin{array}{l}\text { Plots } \\
N=10\end{array}$ & $\begin{array}{l}\text { Plant } \\
\text { C }\end{array}$ & $\begin{array}{l}\% \\
\mathrm{CC}\end{array}$ & $\begin{array}{l}\text { Litter } \\
\mathrm{C}\end{array}$ & $\begin{array}{l}\% \\
\mathrm{CC}\end{array}$ & $\begin{array}{l}\text { Stone } \\
\mathrm{C}\end{array}$ & $\begin{array}{l}\% \\
\mathrm{CC}\end{array}$ & $\begin{array}{l}\text { SOM } \\
\mathrm{C}\end{array}$ & $\begin{array}{l}\% \\
\mathrm{CC}\end{array}$ & $\begin{array}{l}\mathrm{BD} \\
\mathrm{C}\end{array}$ & $\begin{array}{l}\mathrm{g} \mathrm{cm}^{-3} \\
\mathrm{CC}\end{array}$ & $\begin{array}{l}\text { SWC } \\
\text { C }\end{array}$ & $\begin{array}{l}\% \\
\mathrm{CC}\end{array}$ \\
\hline Av & 1.10 & 73.50 & 1.80 & 14.70 & 3.30 & 0.70 & 1.14 & 1.63 & 1.47 & 1.27 & 8.05 & 7.83 \\
\hline $\mathrm{Sd}$ & 1.20 & 7.12 & 1.93 & 2.98 & 1.77 & 0.82 & 0.08 & 0.22 & 0.05 & 0.04 & 0.91 & 1.00 \\
\hline Max & 3.00 & 85.00 & 5.00 & 20.00 & 8.00 & 2.00 & 1.32 & 1.98 & 1.54 & 1.34 & 9.02 & 9.85 \\
\hline Min & 0.00 & 63.00 & 0.00 & 10.00 & 2.00 & 0.00 & 1.05 & 1.26 & 1.39 & 1.19 & 6.68 & 6.66 \\
\hline $\mathrm{VC} \%$ & 108.84 & 9.69 & 107.34 & 20.29 & 53.54 & 117.61 & 6.88 & 13.52 & 3.24 & 3.29 & 11.25 & 12.73 \\
\hline Diff & $P<0.001$ & & $P<0.001$ & & $P<0.001$ & & $P<0.001$ & & $P<0.001$ & & $P=0.615$ & \\
\hline
\end{tabular}

$C$ Control plot, $C C$ catch crop plot, $A v$ average, $S d$ standard deviation, Max maximum, Min minimum, $V C$ variation coefficient $((\mathrm{sd} / \mathrm{Av}) \times 100)$, Diff. statistical significant differences

Significance at $P<0.05$

\subsection{Infiltration Rates}

In Fig. 3, the steady-state infiltration rates showed that CC enhances higher infiltration rates with values ranging from 80.05 till $142.2 \mathrm{~mm} \mathrm{~h}^{-1}$; meanwhile, in the $\mathrm{C}$ plots, the values range from 15.38 till $31.91 \mathrm{~mm} \mathrm{~h}^{-1}$. The average steadystate infiltration rates were 25.53 for $\mathrm{C}$ and $119.35 \mathrm{~mm} \mathrm{~h}^{-1}$ for Catch Crops. There are statistically significant differences among both plots $(P<0.001)$.

\subsection{Runoff Initiation and Runoff Discharge}

The differences between $\mathrm{CC}$ and $\mathrm{C}$ were due mainly to the delay of the runoff initiation and ponding in the CC plots (Fig. 4). Runoff showed statistically significant differences between the input groups control with herbicide and Catch Crops with oat and vetch $(P<0.001)$. Runoff generation was contrasted between Control and Catch Crop plots from the ponding time ( $40 \%$ of the plot ponded) and the runoff outlet. In average values, at the $\mathrm{C}$ plots, ponding was initiated after $67.4 \mathrm{~s}$, the runoff registered after $115.8 \mathrm{~s}$, and the runoff reached the drainage after $265.2 \mathrm{~s}$. The CC plots generated ponding after $141.4 \mathrm{~s}$, runoff after $350 \mathrm{~s}$, and the runoff discharge was measured after $1004.4 \mathrm{~s}$. The delayed runoff generation in catch crops can be calculated with the parameter Tr-Tp and Tro-Tr, which show the delayed time from ponding to runoff and the delay from runoff initiated in the soil surface to reach the plot outlet. For the Control plots, the Tr-Tp and Tro-Tr were 48.4 and $265.2 \mathrm{~s}$, respectively and in average values. For the Catch crops, the average values were 208.6 and $654.4 \mathrm{~s}$.

The data are shown in Fig. 4, exhibiting the delay in the ponding in the $\mathrm{CC}$ as is 2.1 longer than in the $\mathrm{C}$ plots. The delay was longer in the $\operatorname{Tr}$ (3.02 times) and Tro (3.8 times). The largest differences were found when the $\mathrm{Tr}-\mathrm{Tp}$ and Tro-Tr were calculated: 4.31 and 4.38 times delayed. This delay in the runoff generation will also determine a reduction in runoff production. All the values showed statistically significant differences at $P>0.001$. 
Fig. 3 Average infiltration rates in the ten different plots with Catch Crops and without them (left spider web graph, a) and box plot showing the variability of the infiltration rate (right graph). In the box plot graph (b), continuous line: mean values; 5th and 95th percentiles are also represented per box plot

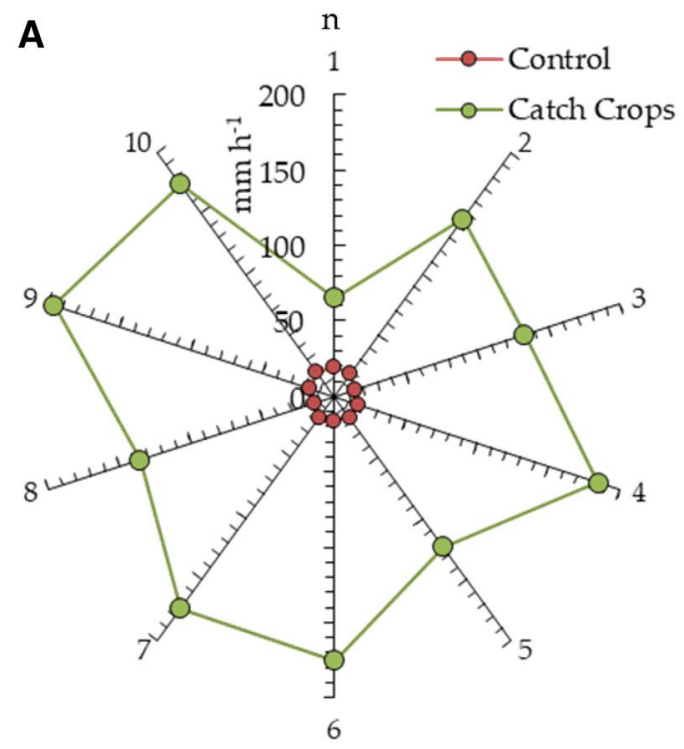

B

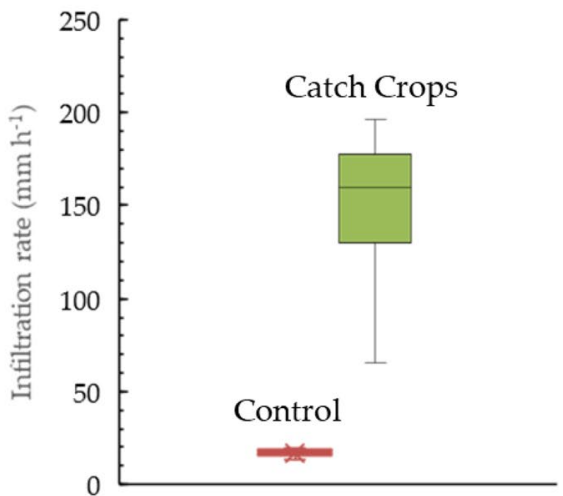

\subsection{Runoff, Sediment Concentration, Sediment Yield and Soil Erosion}

In Fig. 5, runoff and soil erosion results are summarized in different bar graphs to compare other soil management. The $0.25 \mathrm{~m}^{2}$ plots received $13.75 \mathrm{~mm}$ in one hour of rainfall simulated experiment. In average values, the $C$ plots had a runoff discharge of 6.961 . On the contrary, the CC plots reached 0.431 . This is a large difference in the mean runoff coefficient registered at the $\mathrm{C}(50.4 \%)$ and $\mathrm{CC}$ ones (3.1\%).

The amount of soil lost can be assessed by the milkiness of the runoff. The sediment concentration in the runoff was $14.07 \mathrm{~g} \mathrm{l}^{-1}$ and $2.08 \mathrm{~g} \mathrm{l}^{-1}$ in average values for $\mathrm{C}$ and $\mathrm{CC}$, respectively. Sediment concentration ranged from 11.98 till $21.32 \mathrm{~g} \mathrm{l}^{-1}$ in the Control plot and was reduced to $1.25-2.45 \mathrm{~g}^{-1}$ for the $\mathrm{CC}$. The total sediment yield was 98.2 and $0.88 \mathrm{~g}$ for $\mathrm{C}$ and $\mathrm{CC}$, respectively. And they show ranges between 80.32 and $149.62 \mathrm{~g}$ for $\mathrm{C}$ and 0.28 and $1.23 \mathrm{~g}$ for individual plots in CC.

The final results of the amount of runoff and the milkiness of discharge are computed as the soil erosion rate. In $\mathrm{La}$ Florentina fields, the soil erosion response of the Control and Catch Crops plots was contrasted. The average soil erosion rates were $3.93 \mathrm{Mg} \mathrm{ha}^{-1} \mathrm{~h}^{-1}$ and $0.04 \mathrm{Mg} \mathrm{ha}^{-1} \mathrm{~h}^{-1}$ for the $\mathrm{C}$ and $\mathrm{CC}$, respectively. The average values ranged from 3.21 till $5.98 \mathrm{Mg} \mathrm{ha}^{-1} \mathrm{~h}^{-1}$ and from 0.01 and $0.05 \mathrm{Mg} \mathrm{ha}^{-1} \mathrm{~h}^{-1}$ for the $\mathrm{C}$ and $\mathrm{CC}$. The use of catch crops results in a reduction in soil losses by 112 times, two orders of magnitude and the soil losses moved to nominal rates. There was a significant statistical difference between the two managements.

\section{Discussion}

During the 1970's citrus orchards spread inland from the Mediterranean coast, and since 1980 the expansion of citrus orchards reached steeper mountain slopes, which used drip irrigation systems instead of flood irrigation. Terracing and land levelling were not necessary anymore. Since the 1990s, citrus orchards have been established on slopes $>20 \%$, and as a consequence, have high soil erosion risks. Therefore, overall citrus production has moved from valley bottom sites to steeper soils and from a traditional flooding system to a modern, high technology drip irrigation system (Novara et al. 2019; Rodrigo-Comino et al. 2020). Although citrus plantations moved from the alluvial plains to sloping terrains, land management practices have failed to adapt to the new topography. The newly rugged landscapes that have been taken into use ask for new, sustainable strategies to reduce or avoid the associated soil erosion, which so far has not been developed. Consequently, intensive tillage and high herbicide use on these citrus orchards are causing the largest soil losses measured in Spain (García-Ruiz 2010) with other orchards such as vineyards, almonds or olives. Traditional citrus orchards on flat land in river basins have negligible soil losses or accumulate sediments during river flooding. This sedimentation process on the conventional Mediterranean "Huertas" during floods contributed to soil development and the maintenance of soil fertility. However, the detachment of soil particles by water erosion processes on slopes is now contributing to soil degradation on the new citrus plantations, and damages in the infrastructures, and enhancing floods. The recent States-of-the-Art shows that the high soil erosion rates found in La Florentina lighthouse farm are also found in other intensively managed crops with 


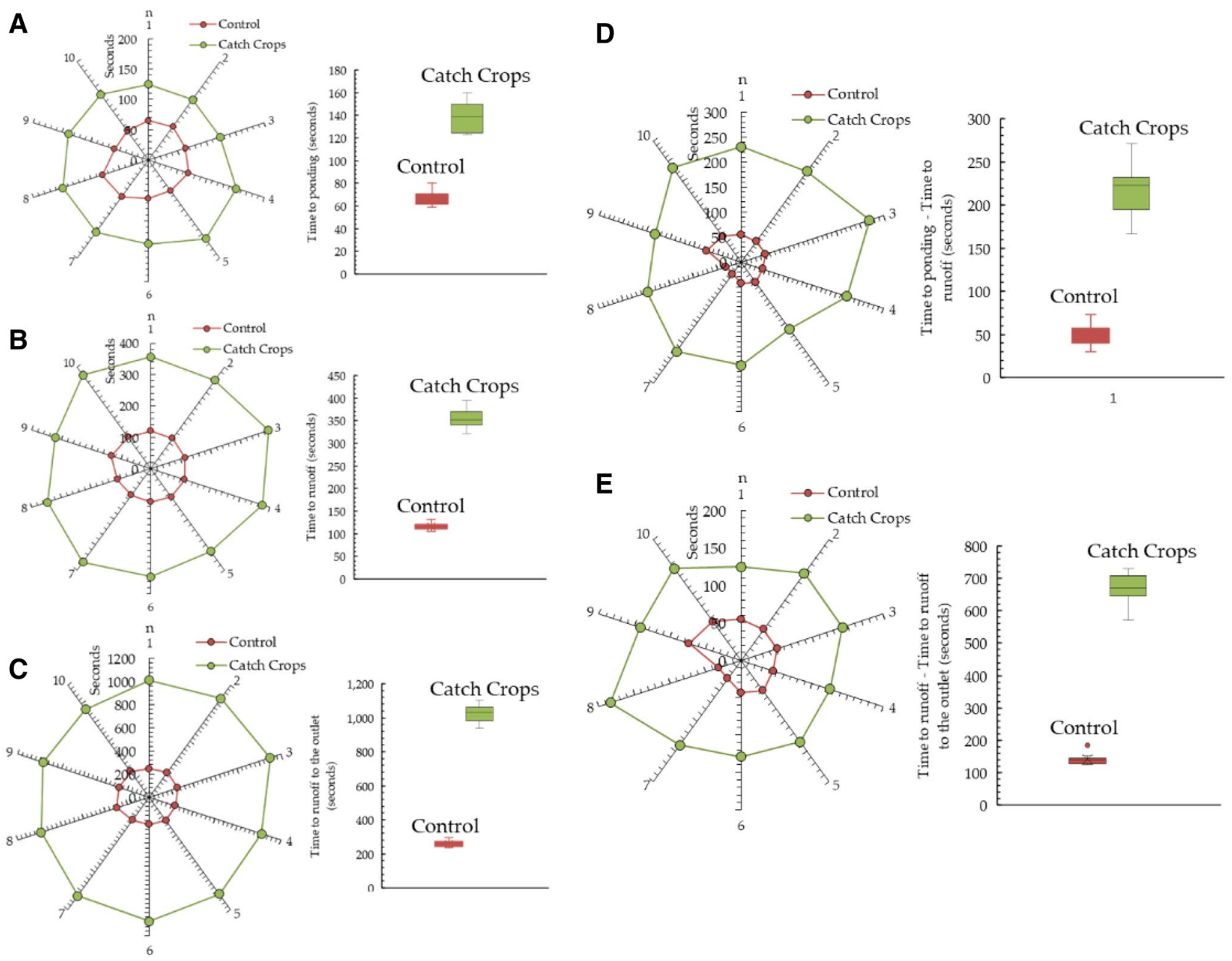

Fig. 4 Runoff parameters related to the hydrological responses in the Catch Crops (CC) and Control plots (C)

chemicals, and show that there is a need to research on the causes of the high erosion rates and to find the correct solutions (Borrelli et al. 2020; García-Ruiz et al. 2017). Chemical farming and the industrialization of agriculture are one of the causes. The positive effect of the Common Agriculture Policy on soil erosion found by Borrelli and Panagos (2020) is not always seen as; still, some farmers decisions do not contribute to sustainable agriculture management (Ben-Salem et al. 2018; Telak et al. 2021).

Figure 6 informs how catch crops induce apparent changes in the soil properties and the runoff and sediment yield. The relationship shown in Fig. 6 demonstrates that the cover of catch crops causes a reduction of the raindrop impact, and then there is a reduction in the soil bulk density that is also remediated by the introduction of organic matter and the litter cover. The biomass generated by the catch crops induces an increase in the steady-state infiltration rate, the origin (shade + water + organic matter) of an increase in the soil biota. This was not registered in our experiments in La Florentina. Still, it was found by other researchers such as Kwiatkowski et al. (2020) and de Pedro et al. (2020) in similar experiments where they compared the biota evolution after a shift in soil management with the soil properties.

The bare soil promoted by conventional farming (treated with agrochemicals and tillage) in citrus plantations is the cause of most of the problems found, as bare soils promote higher runoff rates. Our investigations demonstrate (Fig. 6) that catch crops reduce the runoff coefficient at the pedon scale from 50.6 to 3.1 in a decade; this means that there is a sudden decline in runoff once the catch crops are established. Catch crops induce more infiltration and less runoff, and activation of the soil functions reduces bulk density (Cerdà et al. 2018). The roots developed by the catch crops and the contribution of the organic matter with a recovery of the biological activity of the soil induce the increase in micro and mainly macropores, as was reviewed by BlancoCanqui and Ruis (2020) and Haruna et al. (2020). 
Fig. 5 Soil erosion results were obtained in the Control and Catch Crops plots
A
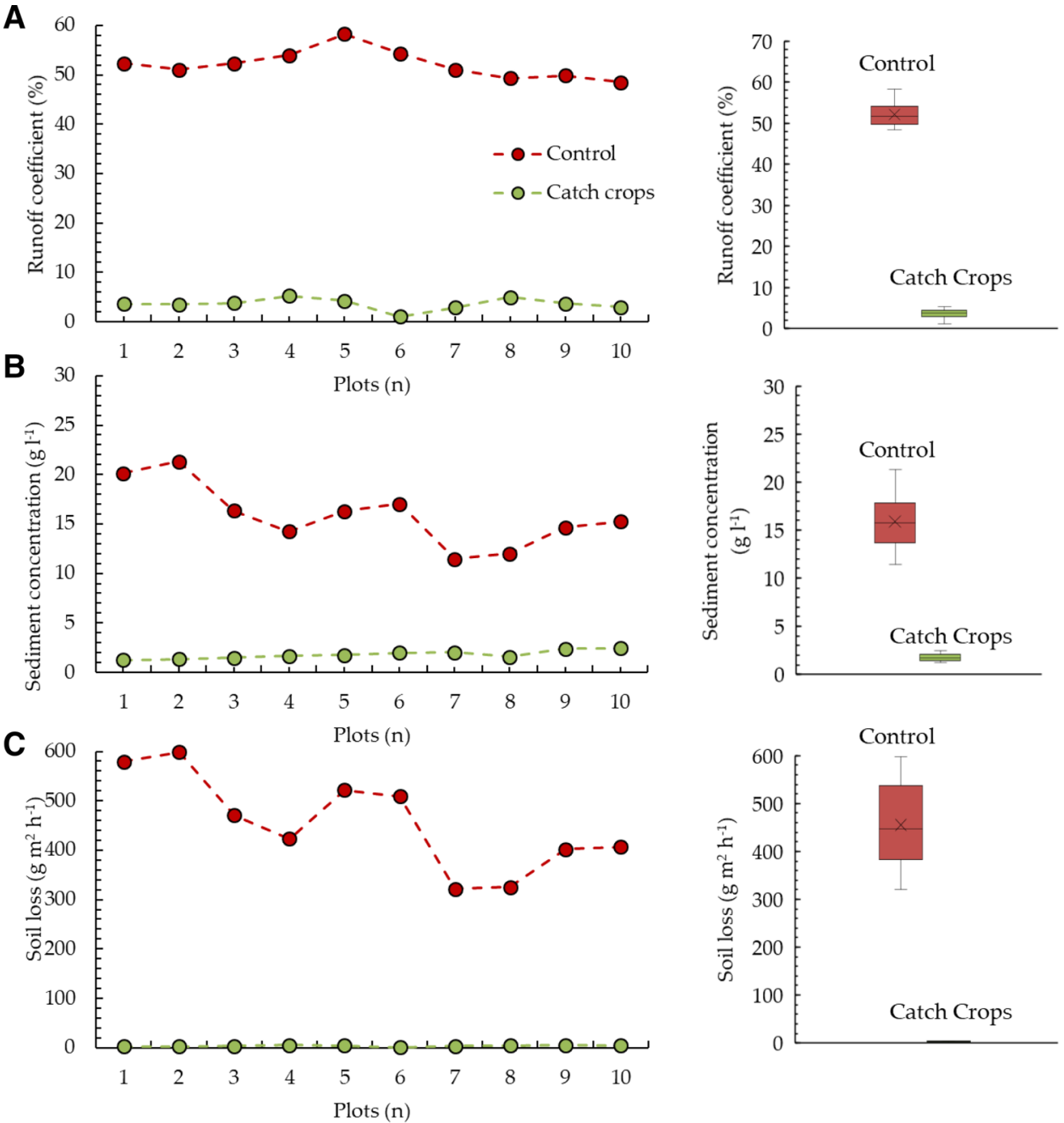

Our statistical analysis demonstrated that almost all the soil properties registered a significant difference among them at $P<0.001$. Only in one case, for SWC, it was obtained similar results $(P=0.615)$. These results can suppose a key tool to understand from the production aspect that during sampling performed in summer in a dry climate such as in Spain the producers with $\mathrm{CC}$ and with herbicide treated soils have equal water status. The use of CC did not imply differences in water status within the soils. This information is worth to be highlighted and discussed from the point of management recommendations and farmers fear due to competition between cultures and grasses for water consumption, which is usual in arid and semi-arid environments like this (Cubera et al. 2012; Delpuech and Metay 2018; Temani et al. 2021). Moreover, the relationships in Fig. 6 demonstrate that once the catch crops establishment reduces the runoff, there is a reduction in the soil erosion rates. The most apparent impact is shown in the soil erodibility (runoff sediment concentration) that move from 14.07 till $2.08 \mathrm{~g} \mathrm{l}^{-1}$ after a decade as a consequence of the cover of catch crops that avoid the raindrop impact and results in more infiltration and less runoff, and the runoff milkiness was reduced in seven times.

The experimental setup developed at the La Florentina lighthouse farm demonstrates a very positive effect of the catch crops to improve the soil quality. More porous soil and a cover of plants contributed to less runoff, and less sediment delivered. A positive reply from the farmers did not follow the success of the biophysical approach. Our interviews demonstrate that most of the farmers do not use, and they do not want to use catch crops. They see the catch crops as dirt, as a problem for their reputation and a new landscape that they did not select was imposed by the governmental agencies. On the other hand, there is a lack of agrarian extension services that will guide and supervise the farmers. Right now, most civil servants at the agrarian extension offices invest most of their time to fill or oversee the management of subsidies. More than bureaucrats, the farmers claim for technicians to be informed.

This negative perception of the farmers results in constraints to the use of catch crops in their fields. But there 

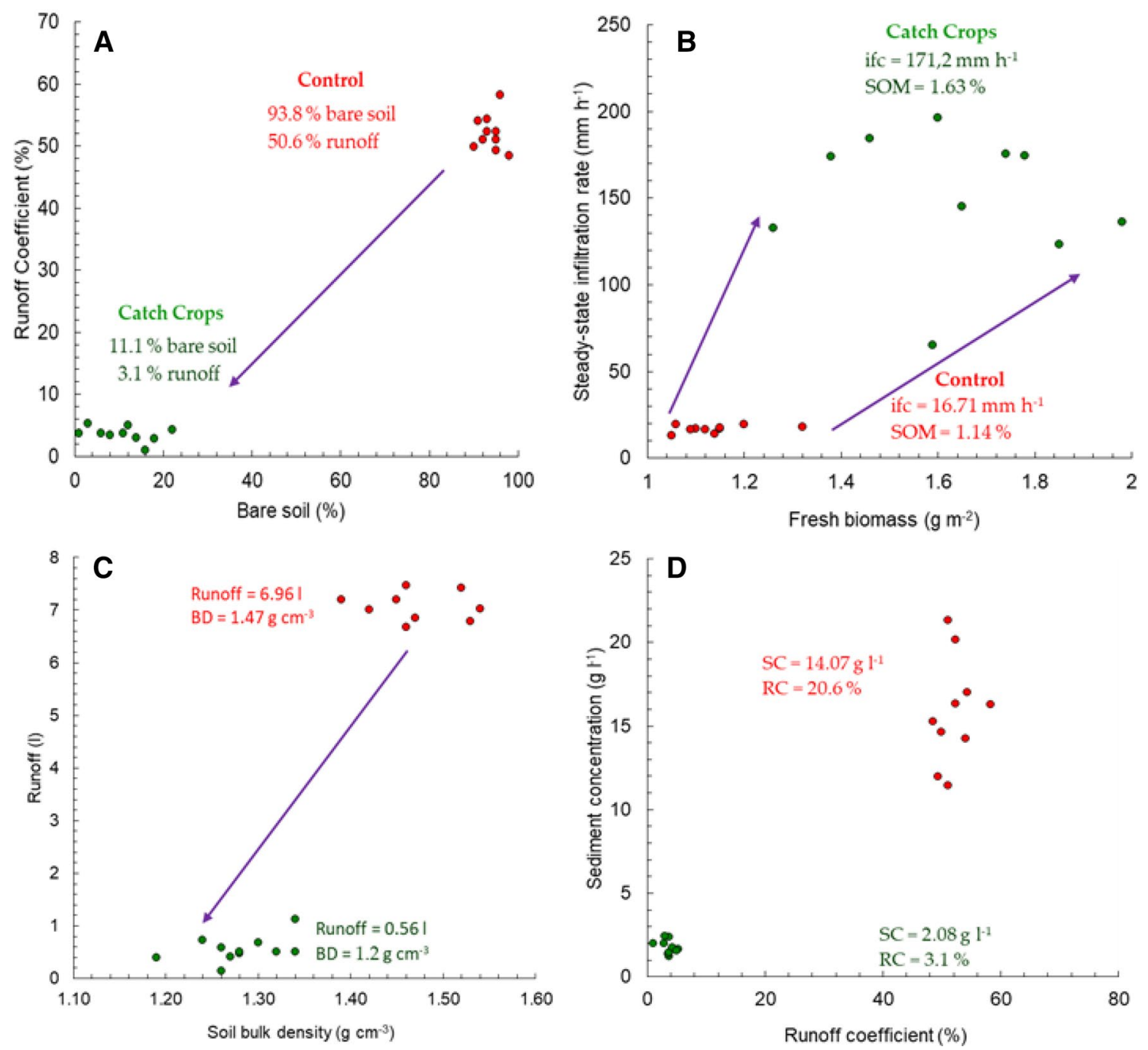

Fig. 6 Linear interrelations between different variables are measured at the plot scale. The introduction of catch crops resulted in changes in soil properties and soil and water losses at La Florentina lighthouse farm

are more constraints based on our interviews that we can deduce and use to start further investigations in the future: (1) the ageing of the farmers' population induces the lack of a new generation of farmers with new education, views and challenges; (2) the uncertainties to find a replacement for the farms is making that farmers do not invest in new managements or new crops; (3) the lack of education from the governmental agencies for the farmers' community in new crops, techniques, management or technology induces the lack of innovation; and finally, (4) there is not a dissemination programme to inform the farmers of their contribution to sustainable agriculture. The farmers accept that a change in the management will be done only if subsidies are paid.

The negative perception of catch crops by the farmers fails the policies that must achieve sustainable management in agricultural land, and this should be solved not only with the subsidies from the Common Agriculture Policy, but it should also be a local, regional and national coordinated effort to achieve the changes. We highly recommend that an active and renewed agrarian extension service could be developed at the district scale to restore the farmers' perception of catch crops. It is necessary to change the fate of the current agriculture and achieve sustainability with new management strategies.

Land management practices on these citrus orchards planted on steep soils are similar, or identical, to the ones applied on the flat traditional-irrigated "Huertas". Tillage and the recurrent use of herbicides (No-Tillage) are increasing, which results in bare soils and high soil erosion rates. Catch crops or allowing weeds to grow is rarely used in Spanish citrus orchards as a strategy to reduce soil erosion. Today's aggressive land management practice with the abuse of glyphosate results in soil degradation, as the organic matter turnover is negligible, the soil is compacted, 
and soil organic matter content is below $1 \%$ in many citrus orchard soils. Our results demonstrated that eroded soils have lower water infiltration rates, greater runoff discharge, and greater flood risk and this will affect runoff connectivity and land degradation (Cerdà et al. 2021a, b; Keesstra et al. 2018c). High runoff from citrus orchards can reduce water quality, increase sediment in the fluvial system, and disturb river biota. These sediments accelerate the siltation of reservoirs, which affect urban water supply, irrigation, and flood control. High use of agrochemicals in citrus orchards also increases water, soil, air pollution, and roads and other infrastructures. Moreover, the use of agrochemicals induces a reduction in soil biota, depletion of organic matter, and degradation of the soil structure. This will result in a loss of soil health.

\section{Conclusions}

The experiments developed at La Florentina lighthouse farm demonstrate that catch crops are very efficient in restoring the soil properties damaged by decades of abuse of herbicides, which can be useful for the whole county. On the other hand, during high-intensity rainfall events and infiltration experiments, the surface wash resulted in high erosion rates in the control plots treated with herbicides and tillage. The soil recovery induces higher infiltration rates, a reduction in runoff delivery and diminish in two orders of magnitude soil losses. However, at "La Ribera del Xúquer" district, where La Florentina farm is located, farmers see catch crops as dirt. Their perception is that using catch crops will reduce their reputation as good farmers. For them, catch crops are not a solution to the problems they face as farmers. They accept that pesticides are dangerous for health but contribute to making their life easier. Farmers will accept to use catch crops if a subsidy would be paid. This perception constraints to the use of catch crops are based on the ageing of the farmers' population, the uncertainties to find a replacement for the farms and the lack of education and dissemination facilities in the region. The farmers' negative perception of catch crops fails the policies that must achieve sustainable management in agricultural land. Robust agrarian extension services are necessary to change the fate of the current agriculture and achieve sustainability with new management strategies.

Acknowledgements We thank Nathalie Elisseou Léglise for her kind management of our financial support. The collaboration of students from the Degree of Geography and Environmental Sciences was fruitful and enjoyable. Thanks to them for all the collaboration in the field and laboratory. The music of Hilari Alonso, Pep Gimeno and Feliu Ventura was an inspiration during the writing of this paper at the COVID19 time. I thank the contribution of Vicent Borrás and La
Florentina Farm for their contribution to new agriculture and Saskia Keesstra for the inspiring conversations about the future of sustainable agriculture. The guidance of colleagues such as Paco Tortosa, Alfons Dominguez and Pep Roselló was very supportive.

Funding Funding for open access charge: Universidad de Granada / CBUA. This research was funded by the European Union Seventh Framework Programme (FP7/2007-2013) under grant agreement $\mathrm{n}^{\circ}$ 603498 (RECARE project). Artemi Cerdà thanks the Co-operative Research programme from the OECD (Biological Resource Management for Sustainable Agricultural Systems) for its support with the 2016 CRP fellowship (OCDE TAD/CRP JA00088807).

\section{Declarations}

Conflict of interest The authors declare no conflict of interest.

Author statements Since humans are involved in our study, we confirmed that: (1) all methods were carried out in accordance with relevant guidelines and regulations; (2) informed consent to participate was obtained from all subjects involved in the study; (3) informed consent to publish was obtained from the people shown in Fig. 2.

Open Access This article is licensed under a Creative Commons Attribution 4.0 International License, which permits use, sharing, adaptation, distribution and reproduction in any medium or format, as long as you give appropriate credit to the original author(s) and the source, provide a link to the Creative Commons licence, and indicate if changes were made. The images or other third party material in this article are included in the article's Creative Commons licence, unless indicated otherwise in a credit line to the material. If material is not included in the article's Creative Commons licence and your intended use is not permitted by statutory regulation or exceeds the permitted use, you will need to obtain permission directly from the copyright holder. To view a copy of this licence, visit http://creativecommons.org/licenses/by/4.0/.

\section{References}

Assefa E, Hans-Rudolf B (2016) Farmers' perception of land degradation and traditional knowledge in Southern Ethiopia-resilience and stability. Land Degrad Dev 27:1552-1561. https://doi.org/ $10.1002 / \mathrm{ldr} .2364$

Bayu EK (2020) Determinant variables for women's participation in soil and water conservation practices in North Western Ethiopia: the case of Shebel Berenta District (Woreda), East Gojjam Zone, Amhara National Regional State. Air Soil Water Res. https://doi. org/10.1177/1178622120942199

Ben-Salem N, Álvarez S, López-Vicente M (2018) Soil and water conservation in Rainfed vineyards with Common Sainfoin and spontaneous vegetation under different ground conditions. Water 10:1058. https://doi.org/10.3390/w10081058

Biratu AA, Asmamaw DK (2016) Farmers' perception of soil erosion and participation in soil and water conservation activities in the Gusha Temela watershed, Arsi, Ethiopia. Int J River Basin Manag 14:329-336. https://doi.org/10.1080/15715124.2016.1167063

Blanco-Canqui H, Ruis SJ (2020) Cover crop impacts on soil physical properties: a review. Soil Sci Soc Am J 84:1527-1576. https://doi. org/10.1002/saj2.20129

Borrelli P, Panagos P (2020) An indicator to reflect the mitigating effect of Common Agricultural Policy on soil erosion. Land Use Policy 92:104467. https://doi.org/10.1016/j.landusepol.2020.104467 
Borrelli P, Robinson DA, Panagos P, Lugato E, Yang JE, Alewell C, Wuepper D, Montanarella L, Ballabio C (2020) Land use and climate change impacts on global soil erosion by water (20152070). PNAS 117:21994-22001. https://doi.org/10.1073/pnas. 2001403117

Bragança I, Mucha AP, Tomasino MP, Santos F, Lemos PC, DelerueMatos C, Domingues VF (2019) Deltamethrin impact in a cabbage planted soil: degradation and effect on microbial community structure. Chemosphere 220:1179-1186. https://doi.org/10.1016/j. chemosphere.2019.01.004

Calatrava J, Franco JA (2020) Diffusion of soil erosion control practices in the Olive Orchards of the Alto Genil Basin (Granada, Spain). Stud Appl Econ 29:359-384. https://doi.org/10.25115/ eea.v29i1.3943

Casalí J, López JJ, Giráldez JV (1999) Ephemeral gully erosion in southern Navarra (Spain). CATENA 36:65-84. https://doi.org/10. 1016/S0341-8162(99)00013-2

Cerdà A, Rodrigo-Comino J (2021) Regional farmers' perception and societal issues in vineyards affected by high erosion rates. Land 10:205. https://doi.org/10.3390/land10020205

Cerdà A, Rodrigo-Comino J, Giménez-Morera A, Keesstra SD (2018) Hydrological and erosional impact and farmer's perception on catch crops and weeds in citrus organic farming in Canyoles river watershed, Eastern Spain. Agric Ecosyst Environ 258:49-58. https://doi.org/10.1016/j.agee.2018.02.015

Cerdà A, Terol E, Daliakopoulos IN (2021b) Weed cover controls soil and water losses in rainfed olive groves in Sierra de Enguera, eastern Iberian Peninsula. J Environ Manag 290:112516. https:// doi.org/10.1016/j.jenvman.2021.112516

Cerdà A, Novara A, Dlapa P, López-Vicente M, Úbeda X, Popovic Z, Mekonnen M, Terol E, Janizadeh S, Mbarki S, Saldanha-Vogelmann E, Hazrati S, Sannigrahi S, Parhizkar M, Giménez-Morera A (2021a) Rainfall and water yield in Macizo del Caroig, Eastern Iberian Peninsula. Event runoff at plot scale during a rare flash flood at the Barranco de Benacancil. Cuadernos De Investigación Geográfica. https://doi.org/10.18172/cig.4833

Cubera E, Moreno G, Solla A, Madeira M (2012) Root system of Quercus suber L. seedlings in response to herbaceous competition and different watering and fertilisation regimes. Agrofor Syst 85:205-214

de Pedro L, Perera-Fernández LG, López-Gallego E, Pérez-Marcos M, Sanchez JA (2020) The effect of cover crops on the biodiversity and abundance of ground-dwelling arthropods in a Mediterranean Pear Orchard. Agronomy 10:580. https://doi.org/10.3390/agron omy 10040580

Delpuech X, Metay A (2018) Adapting cover crop soil coverage to soil depth to limit competition for water in a Mediterranean vineyard. Eur J Agron 97:60-69. https://doi.org/10.1016/j.eja.2018.04.013

Deshpande VV, Telang MS (1950) Pipet method of sedimentation analysis. Rapid determination of distribution of particle size. Anal Chem 22:840-841. https://doi.org/10.1021/ac60042a033

Duan J, Liu Y-J, Yang J, Tang C-J, Shi Z-H (2020) Role of groundcover management in controlling soil erosion under extreme rainfall in citrus orchards of southern China. J Hydrol 582:124290. https:// doi.org/10.1016/j.jhydrol.2019.124290

Ferrara C, Salvati L, Tombolini I (2014) An integrated evaluation of soil resource depletion from diachronic settlement maps and soil cartography in peri-urban Rome, Italy. Geoderma 232-234:394 405. https://doi.org/10.1016/j.geoderma.2014.05.020

García-Ruiz JM (2010) The effects of land uses on soil erosion in Spain: a review. CATENA 81:1-11. https://doi.org/10.1016/j. catena.2010.01.001

García-Ruiz JM, Beguería S, Lana-Renault N, Nadal-Romero E, Cerdà A (2017) Ongoing and emerging questions in water erosion studies. Land Degrad Dev 28:5-21. https://doi.org/10.1002/ldr.2641
García-Ruiz JM, Lasanta T, Nadal-Romero E, Lana-Renault N, Álvarez-Farizo B (2020) Rewilding and restoring cultural landscapes in Mediterranean mountains: opportunities and challenges. Land Use Policy 99:104850. https://doi.org/10.1016/j.landusepol.2020. 104850

García-Ruiz JM, Lasanta T, Ortigosa L, Ruiz-Flaño P, Martí C, González C (1995) Sediment yield under different land uses in the Spanish Pyrenees. Mt Res Dev 15:229-240

Guerra CA, Rosa IMD, Valentini E, Wolf F, Filipponi F, Karger DN, Nguyen Xuan A, Mathieu J, Lavelle P, Eisenhauer N (2020) Global vulnerability of soil ecosystems to erosion. Lands Ecol 35:823-842. https://doi.org/10.1007/s10980-020-00984-z

Guillaume T, Holtkamp AM, Damris M, Brümmer B, Kuzyakov Y (2016) Soil degradation in oil palm and rubber plantations under land resource scarcity. Agric Ecosyst Environ 232:110-118. https://doi.org/10.1016/j.agee.2016.07.002

Haruna SI, Anderson SH, Udawatta RP, Gantzer CJ, Phillips NC, Cui S, Gao Y (2020) Improving soil physical properties through the use of cover crops: a review. Agrosyst Geosci Environ 3:e20105. https://doi.org/10.1002/agg2.20105

Hondebrink MA, Cammeraat LH, Cerdà A (2017) The impact of agricultural management on selected soil properties in citrus orchards in Eastern Spain: a comparison between conventional and organic citrus orchards with drip and flood irrigation. Sci Total Environ 581-582:153-160. https://doi.org/10.1016/j.scito tenv.2016.12.087

IUSS Working Group WRB (2015) World reference base for soil resources 2014, update 2015. International soil classification system for naming soils and creating legends for soil maps. World Soil Resources Reports No. 106. FAO, Roma

Jianjun W, Quansheng L, Lijiao Y (2017) Effect of intercropping on soil erosion in young citrus plantation-a simulation study. Chin J Appl Ecol 8:143-146

Kamau S, Barrios E, Karanja NK, Ayuke FO, Lehmann J (2017) Soil macrofauna abundance under dominant tree species increases along a soil degradation gradient. Soil Biol Biochem 112:35-46. https://doi.org/10.1016/j.soilbio.2017.04.016

Katra I (2020) Soil erosion by wind and dust emission in semi-arid soils due to agricultural activities. Agronomy 10:89. https://doi. org/10.3390/agronomy 10010089

Keesstra S, Mol G, De Leeuw J, Okx J, Molenaar C, De Cleen M, Visser S (2018a) Soil-related sustainable development goals: four concepts to make land degradation neutrality and restoration work. Land 7:133. https://doi.org/10.3390/land7040133

Keesstra S, Nunes J, Novara A, Finger D, Avelar D, Kalantari Z, Cerdà A (2018b) The superior effect of nature based solutions in land management for enhancing ecosystem services. Sci Total Environ 610-611:997-1009. https://doi.org/10.1016/j.scitotenv.2017.08. 077

Keesstra S, Nunes JP, Saco P, Parsons T, Poeppl R, Masselink R, Cerdà A (2018c) The way forward: can connectivity be useful to design better measuring and modelling schemes for water and sediment dynamics? Sci Total Environ 644:1557-1572. https://doi.org/10. 1016/j.scitotenv.2018.06.342

Keesstra S, Sannigrahi S, López-Vicente M, Pulido M, Novara A, Visser S, Kalantari Z (2021) The role of soils in regulation and provision of blue and green water. Philos Trans R Soc B Biol Sci 376:20200175. https://doi.org/10.1098/rstb.2020.0175

Kuzyakov Y, Zamanian K (2019) Reviews and syntheses: Agropedogenesis-humankind as the sixth soil-forming factor and attractors of agricultural soil degradation. Biogeosciences 16:4783-4803. https://doi.org/10.5194/bg-16-4783-2019

Kwiatkowski CA, Harasim E, Feledyn-Szewczyk B, Antonkiewicz J (2020) Enzymatic activity of loess soil in organic and conventional farming systems. Agriculture 10:135. https://doi.org/10. 3390/agriculture10040135 
Lasanta TL, Sobrón I (1988) Influencia de las prácticas de laboreo en la evolución hidromorfológica de suelos cultivados con viñedo. Cuadernos De Investigación Geográfica 14:81-98. https://doi.org/ 10.18172/cig.966

Lieskovský J, Kenderessy P (2014) Modelling the effect of vegetation cover and different tillage practices on soil erosion in vineyards: a case study in Vráble (Slovakia) using WATEM/SEDEM. Land Degrad Dev 25:288-296. https://doi.org/10.1002/ldr.2162

Liu Y, Zhao L, Yu X (2020) A sedimentological connectivity approach for assessing on-site and off-site soil erosion control services. Ecol Ind 115:106434. https://doi.org/10.1016/j.ecolind.2020.106434

Marques M, Ruiz-Colmenero M, Bienes R, García-Díaz A, Sastre B (2020) Effects of a permanent soil cover on water dynamics and wine characteristics in a Steep Vineyard in the Central Spain. Air Soil Water Res. https://doi.org/10.1177/1178622120948069

Martínez-Casasnovas JA, Ramos MC, Ribes-Dasi M (2002) Soil erosion caused by extreme rainfall events: mapping and quantification in agricultural plots from very detailed digital elevation models. Geoderma 105:125-140. https://doi.org/10.1016/S0016-7061(01) 00096-9

Martínez-Valderrama J, Ibáñez J, Del Barrio G, Sanjuán ME, Alcalá FJ, Martínez-Vicente S, Ruiz A, Puigdefábregas J (2016) Present and future of desertification in Spain: implementation of a surveillance system to prevent land degradation. Sci Total Environ 563-564:169-178. https://doi.org/10.1016/j.scitotenv.2016.04.065

Merchán D, Luquin E, Hernández-García I, Campo-Bescós MA, Giménez R, Casalí J, Valle D, de Lersundi J (2019) Dissolved solids and suspended sediment dynamics from five small agricultural watersheds in Navarre, Spain: a 10-year study. CATENA 173:114-130. https://doi.org/10.1016/j.catena.2018.10.013

Minea G, Ioana-Toroimac G, Moro G (2019) The dominant runoff processes on grassland versus bare soil hillslopes in a temperate environment-an experimental study. J Hydrol Hydromech 67:8. https://doi.org/10.2478/johh-2019-0018

Nearing MA, Xie Y, Liu B, Ye Y (2017) Natural and anthropogenic rates of soil erosion. Int Soil Water Conserv Res 5:77-84. https:// doi.org/10.1016/j.iswcr.2017.04.001

Nesshöver C, Assmuth T, Irvine KN, Rusch GM, Waylen KA, Delbaere B, Haase D, Jones-Walters L, Keune H, Kovacs E, Krauze K, Külvik M, Rey F, van Dijk J, Vistad OI, Wilkinson ME, Wittmer H (2017) The science, policy and practice of nature-based solutions: an interdisciplinary perspective. Sci Total Environ 579:1215-1227. https://doi.org/10.1016/j.scitotenv.2016.11.106

Niu YH, Wang L, Wan XG, Peng QZ, Huang Q, Shi ZH (2021) A systematic review of soil erosion in citrus orchards worldwide. CATENA 206:105558. https://doi.org/10.1016/j.catena.2021.105558

Novara A, Cerda A, Barone E, Gristina L (2021) Cover crop management and water conservation in vineyard and olive orchards. Soil Tillage Res 208:104896. https://doi.org/10.1016/j.still.2020. 104896

Novara A, Pulido M, Rodrigo-Comino J, Prima SD, Smith P, Gristina L, Gimenez-Morera A, Terol E, Salesa D, Keesstra S (2019) Long-term organic farming on a citrus plantation results in soil organic carbon recovery. Cuadernos De Investigación Geográfica 45:271-286. https://doi.org/10.18172/cig.3794

Raclot D, Le Bissonnais Y, Louchart X, Andrieux P, Moussa R, Voltz $M$ (2009) Soil tillage and scale effects on erosion from fields to catchment in a Mediterranean vineyard area. Agric Ecosyst Environ 134:201-210. https://doi.org/10.1016/j.agee.2009.06.019

Repullo-Ruibérriz de Torres MA, Ordóñez-Fernández R, Giráldez JV, Márquez-García J, Laguna A, Carbonell-Bojollo R (2018) Efficiency of four different seeded plants and native vegetation as cover crops in the control of soil and carbon losses by water erosion in olive orchards. Land Degrad Dev 29:2278-2290. https:// doi.org/10.1002/ldr.3023
Rodrigo-Comino J, Giménez-Morera A, Panagos P, Pourghasemi HR, Pulido M, Cerdà A (2020) The potential of straw mulch as a nature-based solution for soil erosion in olive plantation treated with glyphosate: a biophysical and socioeconomic assessment. Land Degrad Dev 31:1877-1889. https://doi.org/10.1002/ldr.3305

Rodríguez Sousa AA, Barandica JM, Rescia AJ (2019) Estimation of soil loss tolerance in olive groves as an indicator of sustainability: the case of the Estepa Region (Andalusia, Spain). Agronomy 9:785. https://doi.org/10.3390/agronomy9120785

Sastre B, Barbero-Sierra C, Bienes R, Marques MJ, García-Díaz A (2016) Soil loss in an olive grove in Central Spain under cover crops and tillage treatments, and farmer perceptions. J Soils Sediments. https://doi.org/10.1007/s11368-016-1589-9

Taguas EV, Guzmán E, Guzmán G, Vanwalleghem T, Gómez JA (2015) Characteristics and importance of rill and gully erosion: a case study in a small catchment of a marginal olive grove. Cuadernos De Investigación Geográfica 41:107-126. https://doi.org/10. 18172/cig.2644

Taguas EV, Gómez JA (2015) Vulnerability of olive orchards under the current CAP (Common Agricultural Policy) regulations on soil erosion: a study case in Southern Spain. Land Use Policy 42:683-694. https://doi.org/10.1016/j.landusepol.2014.09.001

Telak LJ, Dugan I, Bogunovic I (2021) Soil management and slope impacts on soil properties, hydrological response, and erosion in Hazelnut Orchard. Soil Syst 5:5. https://doi.org/10.3390/soils ystems5010005

Temani F, Bouaziz A, Daoui K, Wery J, Barkaoui K (2021) Olive agroforestry can improve land productivity even under low water availability in the South Mediterranean. Agric Ecosyst Environ 307:107234. https://doi.org/10.1016/j.agee.2020.107234

Tercan E, Dereli MA (2020) Development of a land suitability model for citrus cultivation using GIS and multi-criteria assessment techniques in Antalya province of Turkey. Ecol Ind 117:106549. https://doi.org/10.1016/j.ecolind.2020.106549

Trivedi P, Delgado-Baquerizo M, Anderson IC, Singh BK (2016) Response of soil properties and microbial communities to agriculture: implications for primary productivity and soil health indicators. Front Plant Sci. https://doi.org/10.3389/fpls.2016.00990

van Leeuwen CCE, Cammeraat ELH, de Vente J, Boix-Fayos C (2019) The evolution of soil conservation policies targeting land abandonment and soil erosion in Spain: a review. Land Use Policy 83:174-186. https://doi.org/10.1016/j.landusepol.2019.01.018

Veerman C, Correia TP, Bastioli B, Biro B, Bouma J, Cienciala E, Emmet B, Frison E, Grand A, Hristov L et al (2020) Caring for soil is caring for life (No. KI-02-20-463-EN-N). European Comission, Brussels

Walkley A, Black IA (1934) An examination of the Degtjareff method for determining soil organic matter, and a proposed modification of the chromic acid titration method. Soil Sci 37:29-38

Wang L, Tang L, Wang X, Chen F (2010) Effects of alley crop planting on soil and nutrient losses in the citrus orchards of the Three Gorges Region. Soil Tillage Res 110:243-250. https://doi.org/10. 1016/j.still.2010.08.012

Xu H, Qi S, Gong P, Liu C, Wang J (2018) Long-term monitoring of citrus orchard dynamics using time-series Landsat data: a case study in southern China. Int J Remote Sens 39:8271-8292. https:// doi.org/10.1080/01431161.2018.1483088

Zhang N, Zhang Q, Li Y, Zeng M, Li W, Chang C, Xu Y, Huang C (2020) Effect of groundcovers on reducing soil erosion and non-point source pollution in citrus orchards on red soil under frequent heavy rainfall. Sustainability 12:1146. https://doi.org/10. 3390/su12031146

Zuazo VHD, Rodríguez BC, García-Tejero IF, Ruiz BG, Tavira SC (2020) Benefits of organic olive rainfed systems to control soil erosion and runoff and improve soil health restoration. Agron Sustain Dev 40:41. https://doi.org/10.1007/s13593-020-00644-1 